\title{
Where does the Coronavirus come from? On the mechanisms underlying the endorsement of conspiracy theories on the origin of SARS-CoV-2
}

\author{
Cristiano Vezzoni* (D), Giulia M. Dotti Sani (D), Antonio M. Chiesi (D), Riccardo Ladini (D), \\ Ferruccio Biolcati (D), Simona Guglielmi (D), Nicola Maggini (D), Marco Maraffi (D), \\ Francesco Molteni (D), Andrea Pedrazzani (i) and Paolo Segatti (i) \\ SPS TREND Lab at the Department of Social and Political Sciences, University of Milan "La Statale", Milano, Italy \\ *Corresponding author. Email: cristiano.vezzoni@unimi.it
}

(Received 7 October 2020; revised 12 April 2021; accepted 14 April 2021; first published online 5 July 2021)

\begin{abstract}
While official science has given its answer to the question on the origin of the Coronavirus (animal to human transmission), alternative theories on human creation of the virus - purposely or inadvertently - have flourished. Those alternative theories can be easily located among the family of conspiracy theories, as they always assume some secretive activity of some groups acting on their self-interest and against the good of the many. The article assesses the prevalence of these beliefs during the COVID-19 pandemic in Italy, studies its development during the pandemic, and investigates its potential determinants. In particular, it analyses the relationship between beliefs in alternative theories on the origin of the virus and political orientation, by arguing that the association cannot be attributed to (politically) motivated reasoning, as the issue has not been highly politicized in the Italian context. Alternatively, the article suggests that the main factor driving beliefs in alternative accounts on the origins of the virus is institutional trust. Political orientation moderates its effects, depending on specific conditions (e.g. cue taking, position of the supported party either in government or opposition), and eventually reinforcing scepticism towards epistemic authorities for those with low trust in institutions. Data come from the ResPOnsE COVID-19 survey, carried out with daily samples from April to July 2020 $(N>15.000)$ to monitor the development of the Italian public opinion during the Coronavirus pandemic.
\end{abstract}

Key words: Conspiracy theory; COVID-19; institutional trust; motivated reasoning; pandemic; partisanship

\section{Introduction}

A year after the first Coronavirus outbreaks, the John Hopkins COVID-19 website ${ }^{1}$ reports almost 120 million confirmed cases of COVID-19 and more than 2.5 million deaths in the 192 countries/ regions affected by the virus. In a brief lapse of time, the world at large was thus confronted with something unknown that rapidly took the shape of the worst pandemic since the Spanish flu, one century ago. At the same time, a stream of research started and in a short period a great deal was known about the virus, ${ }^{2}$ though the areas of uncertainty remained (and remain) large.

\footnotetext{
${ }^{1}$ https://coronavirus.jhu.edu/map.html, accessed on 15 March 2021.

${ }^{2}$ Just to give an idea of the corpus of literature that was suddenly produced on COVID-19-related issues, check the 'COVID-19 Global Literature on Coronavirus disease' archive at https://www.who.int/emergencies/diseases/novel-coronavirus-2019/. The database (accessed on 6 April 2021) counts more than 92,000 full-text articles in English in 2020, and more than 30,000 in the first trimester of 2021.

(c) The Author(s), 2021. Published by Cambridge University Press on behalf of the Società Italiana di Scienza Politica. This is an Open Access article, distributed under the terms of the Creative Commons Attribution-NonCommercial-NoDerivatives licence (http://creativecommons. org/licenses/by-nc-nd/4.0/), which permits non-commercial re-use, distribution, and reproduction in any medium, provided the original work is unaltered and is properly cited. The written permission of Cambridge University Press must be obtained for commercial re-use or in order to create a derivative work.
} 
Together with the disruption brought by the diffusion of the virus, conspiracy theories came and flourished on many aspects of the pandemic (Miller, 2020a, 2020b). One of the discussions that immediately started after the first reports of COVID-19 cases was on the origin of the virus. The geographical area was undisputed (so much that an international controversy occurred after the President of the USA, Donald Trump, labelled the virus as 'Chinese'). ${ }^{3}$ Nonetheless, how the SARS-CoV-2 emerged remained a more disputed issue. There were speculations on a potential human origin of the virus, supposedly not resulting from natural processes. Some sources suggested that the virus was human-made during some secret experiments and purposely released or was the result of a laboratory culture that went out of control. Official science rapidly came to an answer, indicating zoonotic transmission (i.e. from animals to humans) as the most plausible explanation of the origin of the virus, ${ }^{4}$ and ruling out its emergence via laboratory manipulation. Indeed: 'the genetic data irrefutably show that SARS-CoV-2 is not derived from any previously used virus backbone' (Andersen et al., 2020: 450).

However, alternative theories on the origin of the virus branched out among the public. Research found that, respectively, $49 \%$ and $52 \%$ of Americans who participated in a COVID-19 survey in April 2020 hold as probably or definitely true that 'the virus was a biological weapon intentionally released by China' and 'the virus was accidentally released by China' (Miller, 2020a). In another survey dated June 2020, the Pew Research Center found that, 3 months into the pandemic, $71 \%$ of Americans had heard that the COVID-19 outbreak was intentionally planned by people in power, and about one-third of those who heard it said it was probably or definitely true (Mitchell et al., 2020). Already in March 2020, the same institute found that almost one in three Americans believed that COVID-19 was developed intentionally or made accidentally (Mitchell and Oliphant, 2020).

These alternative theories eventually found their way towards the highest spheres, as the president of the United States Donald J. Trump claimed to have evidence that the Coronavirus originated at the Wuhan Institute of Virology (Guardian, 2020b), even if the same story was later categorically dismissed by the US administration top-ranking expert on the Coronavirus, doctor Anthony Fauci (National Geographic, 2020).

The spreading of these alternative accounts on the origin of the virus was not bounded to the US. Also in Italy, suggestions of a potential human manipulation of the virus were embraced by public officers (such as the President of the Veneto region Luca Zaia, Repubblica, 2020), although the topic did not reach prominence and remained limited only to that extemporary statement. ${ }^{5}$

\section{Aim of the study and hypotheses}

The controversy on the origin of the virus supplies an excellent opportunity to study the mechanisms underlying the endorsement of conspiracy theories. In fact, Alternative Theories on the Origin of the Coronavirus (from now on, ATOCs) - purposely or accidentally released from a laboratory, secret warfare, etc. - assume that citizens are not aware of the secret plans of a

\footnotetext{
${ }^{3}$ In a Tweet dated 16 March 2020, Trump states: 'The United States will be powerfully supporting those industries, like Airlines and others, that are particularly affected by the Chinese Virus. We will be stronger than ever before!' Given the harsh reply from Chinese authorities, Trump continued, in a press conference hold on 18 March 2020: 'Calling it the "Chinese virus" is not racist at all, it comes from China' (Guardian, 2020a).

${ }^{4}$ Very quickly after the first cases of COVID-19, it was established that the most likely origin of SARS-COV-2 was to be found in the Chinese horseshoe bats (Zhou et al., 2020). In this case, the cause should have been a direct zoonotic transmission. Nonetheless, it has been shown that transmission to humans can have happened through other species of mammals and birds acting as intermediate host (Qiu et al., 2020). In March 2021, the World Health Organization published a report resulting from a WHO-convened global study on the origin of SARS-CoV2, indicating the introduction through an intermediate host to be the most likely pathway of the virus to human beings. The report also states that introduction through a laboratory incident was considered to be an extremely unlikely pathway' of SARS-Cov2 to humans (World Health Organization, 2021).

${ }^{5}$ It is worth to notice that in a previous occasion, the same officer was forced to apologize after stating that 'I think China has paid a big price for this epidemic because, after all, we have all seen them eating mice alive, or things like that' (translation of the authors) (Reuters, 2020).
} 
minority of powerful people (Sunstein and Vermeule, 2009) concerning relevant events that are occurring (Uscinski and Parent, 2014). In short, ATOCs clearly entangle elements of conspiratorial ideation. Moreover, on the specific matter, there is an official answer universally accepted by the scientific community that attributes the outbreak of the Coronavirus to the transmission from animal to human (zoonosis, being AIDS, Ebola, bubonic plague examples of this process). The existence of such an answer does exempt us from speculating on the degree of truth of this statement compared to the others. We thus simply name it the 'officially recognized origin'.

The first aim of our study is to detect and describe the prevalence of beliefs in ATOCs in the Italian context. The Italian case is especially interesting to study the diffusion of ATOCs among the population not only because Italy was hit by the health emergency earlier than any other Western country, thus in a time with greater uncertainty about the virus, but also because unlike in other contexts, the 'official' origin of the SARS-CoV-2 virus was not strongly questioned in the public debate and discussions on the topic were only partially politicized.

Secondly, we study which dimensions are associated with beliefs in ATOCs. From a first inspection of the literature, we can expect these beliefs to be associated with the following dimensions: (1) conspiratorial thinking (Uscinski and Parent, 2014); (2) the perception of personal risks induced by situational factors, that is, the specific uncertain conditions related to the COVID-19 pandemic (van Prooijen and Acker, 2015; Miller, 2020b); (3) general attitudinal elements, basically referring to trust in institutions (Einstein and Glick, 2015; Miller et al., 2016; Šrol et al. 2021); (4) political orientation (Miller et al., 2016).

As for the first dimension, conspiratorial thinking, also referred to as conspiratorial predispositions (Uscinski et al., 2016) and conspiratorial ideation (Brotherton et al., 2013), is intended as 'an individual's underlying propensity to view the world in conspiratorial terms' (Uscinski et al., 2016: 58). Therefore, an association between conspiratorial thinking and beliefs in ATOCs is expected to hold if these alternative narratives on the origin of the virus share the structure of conspiracy theories. As mentioned above, there is little doubt that this is the case. The existence of the association simply confirms the fact that our assumption on the nature of ATOCs is correct. Following this line of argumentation, our first hypothesis is as follows:

HYPOTHESIS 1: The probability of backing ATOCs is higher for those who are more susceptible to conspiratorial thinking.

The second dimension looks at the situational factors that can ignite beliefs in alternative accounts, given the increased level of uncertainty produced in the environment by the spreading of the Coronavirus (Miller, 2020b). A societal threat can reduce the sense of control, enhance existential insecurity and, accordingly, foster beliefs in what can be defined as the 'unofficial truth' (van Prooijen and Acker, 2015; Douglas et al., 2017). This process does not affect all people in the same way. What translates a societal threat in a situational element impacting on one's beliefs is the way such threat is individually perceived. In this respect, people who have a higher perception of risk are expected to cope with it by believing in alternative narratives detecting agency in the origin of the virus. Indeed, as shown by recent research (Šrol et al., 2021), that perception of risk is positively associated with several COVID-19-related conspiracy theories. ${ }^{6}$

Therefore, our second hypothesis is:

HYPOTHESIS 2: The probability of backing ATOCs is higher for those who perceive a higher health or economic risk related to the spreading of the virus.

\footnotetext{
${ }^{6}$ The same study (Šrol et al., 2021) reports that people with a lower perception of risk are more likely to believe in COVID-19 conspiracy theories denying the existence of the virus. Those people tend to downplay the impact of the pandemic and, accordingly, are more likely to think that COVID-19 is either a common flu or a hoax. Nonetheless, all the ATOCs here considered never question the existence of the virus.
} 
Moving forward in the inquiry on the determinants of beliefs in ATOCs, we consider the lack of trust in institutions as a major underlying determinant of a generalized scepticism in the 'official truth'. The role of institutional trust in the individual mechanisms that determine beliefs in conspiracy theories has been recognized in previous literature, either as a moderating factor (Miller et al., 2016) or as a direct influence in the specific case of conspiracy theories related to COVID-19 (Šrol et al., 2021). The latter underlines especially the feeling of lack of control when one does not trust those institutions that should handle the pandemic crisis. In our case, we consider the fact that the 'official truth' comes from those institutional authorities that should provide explanations for major societal events. Distrust in those institutions brings to disregard official accounts, although the need to understand remains. As an alternative, conspiracy theories offer explanations that do not require to submit to an epistemic authority (Sunstein and Vermeule, 2009). Our third hypothesis thus reads:

HYPOTHESIS 3: The probability of backing ATOCs is higher for those who show low trust in institutions (institutional trust effect).

As for the fourth dimension, a broad corpus of literature has shown that believing in conspiracy theories is not politically neutral. It often entangles a partisan component and people tend to believe more in conspiracies that put their political opponents in a negative light (Miller et al., 2016). In the recent pandemic context, research from the US has shown that beliefs on contentious issues related to the Coronavirus acquired a strong partisan component in the context of a polarized Presidential campaign heavily affected by the pandemic (Mitchell et al., 2020; Mitchell and Oliphant, 2020; Miller, 2020b). This is coherent with the idea that the endorsement of conspiracy theories originates in a process of (politically) motivated reasoning, aimed at bringing discredit to attitude-challenging information (Lodge and Taber, 2000; Miller et al., 2016).

In the Italian situation, however, we lack a fundamental element when considering the issue of the origin of the virus. This issue was not an object of partisan mobilization. No parties or movements officially backed any of the alternative theories. This element should exclude politically motivated reasoning as one of the main mechanisms to explain beliefs in ATOCs.

Nonetheless, there are good reasons not to exclude an association between beliefs in alternative narratives and political orientation. Firstly, a broad stream of research has shown that beliefs in conspiracy theories are often not equally distributed among voters and that conservatives have a higher probability of expressing these opinions (Blank and Shaw, 2015; Nisbet et al., 2015). ${ }^{7}$ In the Italian context, it is difficult to find a working operationalization of conservative and liberal political orientation. Nonetheless, previous research has shown that the supporters of right-wing and populist parties, namely the League (Lega) and the Five Star Movement (M5s), have shown a higher propensity to back conspiracy theories, independently from their content (Mancosu et al., 2017). This finding is relevant as long as we remember that both parties have been able to collect votes from large portions of the Italian electorate (M5s almost 11 million votes in the last Parliamentary election, 2018; Lega more than 9 million votes in the 2019 European Elections).

We thus can offer a first expectation on the direction of the association between political orientation and beliefs in the origin of the Coronavirus:

HYPOTHESIS 4: The probability of backing ATOCs is higher for those closer to right-wing and populist parties, namely Lega and M5s (political orientation effect).

This effect should otherwise be qualified as we can expect a difference in the electorates of Lega and M5s. Firstly, after the fall of the coalition government in which Lega and M5s

\footnotetext{
${ }^{7}$ The results on this matter are not always consistent. For contrasting empirical evidence in that respect, see Oliver and Wood (2014); Uscinski and Parent (2014).
} 
participated as partners from June 2018 to August 2019 (the so-called Yellow-Green coalition), the two parties were on opposite fronts when the data used were collected. The M5s was a member of the Yellow-Red coalition government, with the largest number of MPs in the coalition. ${ }^{8}$ Meanwhile, Lega was the leading actor of the opposition, being the largest and most significant right-wing Italian party. Previous research has shown that conspiracy theories are more likely to emerge to discredit the parties currently in government rather than ones in the opposition, suggesting the existence of a so-called 'loser effect' (Uscinski and Parent, 2014). These findings do not concern individual effects (i.e. higher propensity to believe in conspiracy theories for voters of parties in the opposition). However, in the specific situation of the COVID-19 pandemic in Italy, we can speculate that the opposition can profit from discrediting the government on its performance in handling the crisis, insinuating that the government is not telling citizens all the truth about the pandemic.

Secondly, it has been mentioned earlier that some prominent politicians of Lega backed these alternative accounts, offering partisan cues to their supporters. ${ }^{9}$ In this case, the mechanism would be amenable to cue-taking (Zaller, 1992; Uscinski et al., 2016), reinforcing the previously mentioned loser effect. Even if the issue was not politicized, Lega supporters could have developed a proportionally higher propensity to support an alternative account on a specific event, following cues disseminated in idiosyncratic statements by prominent characters of that party.

These suggestions can foster beliefs in ATOCs as an alternative to the 'official truth', especially among the supporters of those parties insinuating these accounts. The idea is thus that the propensity to believe in ATOCs increases for people leaning on the 'losers' side, especially when this side offers cues in that direction. We can therefore expect that:

HYPOTHESIS 4_bis: the probability of backing ATOCs is higher for respondents close to Lega when compared to those close to the M5s (cue-taking effect).

Previous research also suggested that trust can be a moderator of the relation between political orientation and beliefs in conspiracy theories, thus calling for an interaction between the two dimensions. The role of institutional trust can vary depending on the specific political orientation of the subjects considered, being them liberals or conservatives (Miller et al., 2016). Such a theoretical model looks at political orientation as the most persistent trait in the attitudinal constellation of a person. This assumption is possibly realistic in the US context. Nonetheless, such an assumption is patently untenable in most European political systems. In fact, in recent years, most Western European political systems have been characterized by a profound change of their party systems and high levels of electorate volatility (Chiaramonte and Emanuele, 2017; Emanuele and Chiaramonte, 2019) and this is particularly true for Italy (Emanuele and Chiaramonte, 2020). Consequently, in those contexts, political orientation, especially when measured with proxy variables referring to some form of vote intention, preference or utility, is hard to be thought as a stable, persisting individual trait.

We thus suggest reframing Miller et al.'s model by considering trust as the pivotal and most resilient element in steering beliefs on conspiratorial theories in general, and alternative theories on the origin of the virus in the specific. Political orientation can then act as a moderator of the effect of institutional trust. More specifically, the effect of trust can be amplified by those political preferences that have already proven to be associated with a higher propensity to endorse conspiracy theories. The argument to support this expectation departs from the one used by Miller et al.,

\footnotetext{
${ }^{8}$ The other major partner was the Democratic Party, which belongs to the Progressive Alliance of Socialists \& Democrats group in the European Parliament.

${ }^{9}$ In addition to the Luca Zaia's statement, on 25 March 2020, the leader of Lega, Matteo Salvini, posted on his Facebook page a video-report stating that Coronavirus was artificially created in Chinese laboratories, erroneously reporting results of previous research presented in a televised scientific magazine (Ansa, 2020).
} 
building on Kunda's idea of the conditionality of motivated reasoning (Kunda, 1990). Our view is that lack of trust brings to a higher probability to dismiss the 'official truth', and this mechanism is fostered by coherent attitudinal dispositions (political orientation) and availability of alternative truths (partisan cues). This is perfectly in line with the conditions experienced by Lega's supporters. Nonetheless, the attitudinal coherence between political preferences and (dis-)trust in institutions is hindered when the supported party is in government, as the party becomes a spokesman of the 'official truth'. This is the case of the M5s. Summarizing the argument, we hold that the political orientation of an individual can either amplify or dampen the effect ${ }^{10}$ of trust, depending on the coherence of political orientation with other elements that foster beliefs in ATOCs. We test this expectation comparing supporters of Lega and M5s, and we thus expect that:

HYPOTHESIS 5: The association between institutional trust and the probability of backing ATOCs is greater for those close to Lega when compared to those close to the M5s.

\section{Data, variables and method \\ Data}

The analyses are based on data from the ResPOnsE COVID-19 survey, which was fielded for 90 consecutive days between April and July 2020 in Italy, the first European country to be hit by the SARS-CoV-2 virus in late February (Vezzoni et al., 2020). ResPOnsE COVID-19 is a rolling cross-section survey designed to monitor changes in public opinion during the pandemic (Johnston and Brady, 2002; Johnston, 2008). The gross sample, which is derived from an opt-in online community of a commercial research institute (SWG SpA), was composed of 33,000 individuals, with quotas for area of residence, gender and age group. In line with the rolling cross-section design of the survey, the gross sample was divided into 90 subsamples, one for each day of the fieldwork period. Each respondent received an invitation via e-mail to answer the questionnaire, depending on the subsample they belonged to. The invitation remained active all along the fieldwork and therefore a respondent could fill in the questionnaire at any time following the invitation. Once the survey was launched, an average of 165 interviews were collected each day, yielding a total of over 1000 per week and a grand total of 15,773 interviews on 9 July. The ResPOnsE COVID-19 questionnaire was administered via CAWI (Computer Assisted Web Interviewing) and required approximately $25 \mathrm{~min}$ to complete. The questionnaire covers topics such as behaviour compliance; media use; evaluation of the local and national political institutions; trust in institutions and political attitudes; perception of the health risks tied to the COVID-19 pandemic and opinions about science. Basic socio-demographic characteristics of the respondents such as age, gender, employment status and level of education are also included in the survey. A small part of the questionnaire is time-varying and is devoted to the collection of data on specific topics for shorter periods of time or the insertion of single questions on issues that emerged during the COVID-19 emergency.

For the analyses, we drop the observations from the first and the last days of fieldwork, when the daily samples were not yet balanced between 'fresh' and 'old' respondents (Brady and Johnston, 2006, 2015). Therefore, our analytical sample consists of people who answered the questionnaire from 13 April to 4 July 2020. Overall, after listwise deletion of missing cases on the variables of interest described below, our sample consists of 12,573 women and men aged $18-90$.

A known limitation of data collected via CAWI lies in the fact that not all subjects belonging to the population of interest have the same chances of participating in the survey, and therefore

\footnotetext{
${ }^{10}$ The term 'effect' is used here to exemplify the reasoning underlying the hypothesis and does not imply a causal relationship.
} 
certain categories of individuals are less likely to be represented (typically the elderly and the less educated). Accordingly, post-stratification weights - constructed from the cross-classification of gender, age group, education and macro-area of residence - are applied to the summary statistics presented in Table 1 - while the multivariate models all control for these variables.

\section{Dependent variable: beliefs on the origin of SARS-CoV-19}

Our main dependent variable aims at capturing the respondents' knowledge of the probable origin of the SARS-CoV-2 outbreak. Four response options were provided: (1) failed scientific experiments; (2) a war between the US and China for world supremacy; (3) the passage of a virus from animals to humans; (4) I don't know. ${ }^{11}$ Option (3) is the only one that has received scientific validation (Andersen et al., 2020) and can therefore be considered the officially recognized option. The distribution of the dependent variable is provided in Table 1. As can be seen, about $40 \%$ of respondents gave the scientifically validated answer, indicating that the SARS-CoV-2 outbreak occurred because the virus passed from animals to humans. Another sizable proportion of subjects answered that SARS-CoV-2 is the result of scientific experiments that went wrong (33\%), while about $13 \%$ mentioned a war between the US and China as the most probable origin. Finally, about $14 \%$ said they did not know where the virus could have come from.

\section{Independent and control variables}

Our first independent variable taps a crucial element of conspiratorial thinking (Uscinski and Parent, 2014) and measures the extent to which respondents agree with the statement that the real data on COVID-19 in the country is being kept secret. It ranges from 0 (completely disagree) to 10 (completely agree).

We then include variables tapping the feelings of insecurity, both economic and concerning the risk of being infected. The first is measured through a question asking whether the economic situation of the household has changed since the outbreak. It takes three categories: the situation has remained the same or improved (reference category), the situation has worsened, the situation has worsened a lot. The second variable asks whether the subject feels more at risk of being infected compared to the rest of the population, vs. less at risk or having the same risk (reference category).

To account for whether institutional trust plays a role in the endorsement of the officially recognized cause of the virus, we include a variable gauging trust in the national parliament that ranges from 0 (no trust at all) to 10 (complete trust).

Propensity to vote has been preferred to left-right self-placement as the indicator of political orientation because the relation between the left-right dimension and conspiratorial beliefs has not been thematized in the Italian context and previous research has shown a stronger association with voting right-wing and populist parties (Mancosu et al., 2017). Thus, political orientation is measured through propensity to vote (ptv) for Lega and the M5s, respectively. The original ptv variables result from a battery of questions asking how likely the respondent is to vote for a given party on a range from 0 (not at all likely) to 10 (extremely likely). Those variables were then recoded into dichotomous ones to distinguish subjects with a 'high' ptv for a given party (values equal to or higher than 6) from subjects with a low propensity to vote for that party (values $\leqslant 5$ ).

Finally, our models control for age, gender, level of education (primary, secondary and tertiary), area of residence (North West, North East, Centre, South, Islands) and main activity

\footnotetext{
${ }^{11}$ In Italian, the question reads: F9 Qual è secondo lei la più probabile origine del virus? (1) Esperimenti scientifici sbagliati; (2) Guerra tra USA e Cina per la supremazia mondiale; (3) Il passaggio da animali selvatici all'uomo; (4) Non saprei. The order of the first three answer categories was randomized.
} 
Table 1. Summary statistics

\begin{tabular}{|c|c|c|}
\hline & Mean/pr. & SD \\
\hline \multicolumn{3}{|l|}{ Probable origin of virus } \\
\hline Failed scientific experiments & 32.85 & \\
\hline War between US and China & 12.83 & \\
\hline Official explanation & 40.56 & \\
\hline Don't know & 13.76 & \\
\hline Age (range: 18-90) & 49.68 & 17.56 \\
\hline Hiding real number of cases (range: $0-10$ ) & 5.07 & 3.27 \\
\hline Trust in parliament (range: $0-10$ ) & 4.56 & 2.76 \\
\hline Women & 49.51 & \\
\hline \multicolumn{3}{|l|}{ Area } \\
\hline North west & 27.37 & \\
\hline North east & 19.57 & \\
\hline Center & 19.37 & \\
\hline South & 22.03 & \\
\hline Islands & 11.67 & \\
\hline \multicolumn{3}{|l|}{ Level of education } \\
\hline Primary & 46.26 & \\
\hline Secondary & 37.85 & \\
\hline Tertiary & 15.89 & \\
\hline \multicolumn{3}{|l|}{ Main activity status } \\
\hline Employed & 48.38 & \\
\hline Retired & 21.03 & \\
\hline Homemaker & 10.67 & \\
\hline Student & 8.04 & \\
\hline Unemployed & 10.19 & \\
\hline Other & 1.68 & \\
\hline \multicolumn{3}{|l|}{ Economic situation since COVID-19 emergency } \\
\hline Same or better & 63.17 & \\
\hline Worsened & 26.85 & \\
\hline Worsened a lot & 9.98 & \\
\hline \multicolumn{3}{|l|}{ Risk of being infected compared to population } \\
\hline Less & 11.65 & \\
\hline The same & 47.21 & \\
\hline More & 41.14 & \\
\hline \multicolumn{3}{|l|}{ High propensity to vote } \\
\hline Lega & 27.99 & \\
\hline Five Star Movement & 24.30 & \\
\hline
\end{tabular}

$N=12,573$. Post stratification weights are applied.

(employed, retired, homemaker, student, unemployed, other). These controls allow to consider whether compositional effects can affect the relations we are studying. Controls for age, gender, education and income are common in literature (Miller, 2020a, 2020b). In our case, the latter was not available in the data and we replaced it with respondents' main activity, considering that some conditions (retirement, unemployment) can capture marginality. Finally, we considered geographical area of residence, as for the Italian context this is one of the main dimensions to consider when looking at public opinion, in particular in connection with political orientation (Shin and Agnew, 2008).

\section{Models}

Given the categorical nature of our dependent variable, multinomial logistic regressions are the most appropriate tool to test the association between the outcomes and the predictors of interest (Long and Freese, 2014). We run a first model with only the control variables (Model 1); we subsequently add the variable gauging whether real data on the pandemic in the country are being kept secret (Model 2); in a third model, we include variables concerning feelings of economic and 
health insecurity (Model 3), while Model 4 includes trust in the national parliament. Model 5 includes the two variables tapping the dichotomized propensities to vote for Lega and M5s; and, finally, Model 6 includes the interactions between trust in parliament and the dichotomized propensities to vote for the two parties. For space limitations, we report only the coefficients for the main variables of interest from Models 5 and 6 in Tables 2 and 3, respectively, while the full models are reported in online Appendix Table A1.

\section{The determinants of beliefs in ATOCs}

Starting from Model $5^{12}$ in Table 2, we may notice that our variable tapping into conspiratorial thinking (i.e. believing that real data on contagions in the country are being kept secret) is associated with a higher chance of believing in both ATOCs, as expected (Hypothesis 1). For example, those who completely agree with the statement have a probability of 0.43 of saying that the SARS-CoV-2 was caused by failed scientific experiments, while the probability is 0.15 for those who completely disagree. Similarly, the probability of believing that the cause is a war between the US and China is 0.20 for those who completely agree and 0.03 for those who completely disagree. Overall, the result is in line with our theoretical expectations regarding the link between beliefs in alternative theories on the origin of the virus and conspiratorial thinking. As said, this hypothesis merely serves as a validation of the idea that beliefs on the origin of the virus belong to the broader family of conspirational theories, and confirms our assumption about the nature of our dependent variable.

Moving to the results concerning feelings of uncertainty connected with the perception of personal risks, Model 5 also shows that subjects who were hit worse in economic terms are more likely to believe in alternative explanations, coherently with our expectations (Hypothesis 2). In particular, subjects who report that their economic situation has worsened a lot during the crisis have considerably higher chances of believing in alternative explanations. In contrast, we find only minor differences between people who feel more at risk of being infected and those feeling less at risk, and it only concerns those who believe that the cause of the virus is a war between the US and China.

The coefficient of trust in institutions (Hypothesis 3) is negative as expected: the higher the level of trust, the lower the chance of believing in alternative explanations for the COVID-19 outbreak. Indeed, subjects with no trust at all in the national parliament have a probability of 0.37 and 0.11 of believing that the causes of the SARS-CoV-2 virus were, respectively, failed scientific experiments and the war between the US and China. The predicted probabilities for those who completely trust the national parliament are half as large: 0.19 and 0.06 .

For what concerns political orientation, we can note that having a high propensity ( $\mathrm{ptv} \geqslant$ 6) to vote for Lega or M5s is associated with a considerably greater chance of believing in alternative explanations. The baseline probability of answering 'war between US and China' is much lower, but even in this case, we find that respondents with a high propensity to vote for Lega and M5s have a somewhat higher probability of choosing this outcome when compared to other respondents. Both these results thus support Hypothesis 4. However, the coefficients for Lega are in both cases considerably larger than the ones for the M5s. For example, for those with a high propensity to vote for Lega, the probability of answering 'failed scientific experiments' is 0.45 against 0.30 for those with a high propensity to vote for the M5s. These results support our second hypothesis related to political orientation, which indicates an additional effect given by cue-taking and, possibly, by a 'loser' effect, that is the additional boost that voters of Lega have due to their support for a party in the opposition (Hypothesis 4_bis).

\footnotetext{
${ }^{12}$ We limit our comment to Models 5 and 6 because the sign and magnitude of the coefficients of interest remain constant across the different specifications of the models, as can be seen from the full models reported in the Appendix.
} 
Table 2. Multinomial logit model (Model 5) predicting the probable origin of SARS-CoV-2, r.c.: official explanation

\begin{tabular}{|c|c|c|c|}
\hline & \multicolumn{3}{|c|}{ Model 5} \\
\hline & Scientific experiments & War US and China & Don't know \\
\hline Hiding real number of cases & $\begin{array}{l}0.215^{\star \star \star} \\
(0.008)\end{array}$ & $\begin{array}{l}0.290^{\star \star \star} \\
(0.012)\end{array}$ & $\begin{array}{l}0.118^{\star \star \star} \\
(0.009)\end{array}$ \\
\hline \multicolumn{4}{|c|}{ Change in economic situation (r.c. no change) } \\
\hline Worsened & $\begin{array}{l}0.214^{\star \star \star} \\
(0.054)\end{array}$ & $\begin{array}{c}0.166^{\star} \\
(0.076)\end{array}$ & $\begin{array}{c}0.104 \\
(0.064)\end{array}$ \\
\hline Worsened a lot & $\begin{array}{l}0.407^{\star \star \star} \\
(0.089)\end{array}$ & $\begin{array}{l}0.498^{\star \star \star} \\
(0.114)\end{array}$ & $\begin{array}{c}0.268^{\star} \\
(0.107)\end{array}$ \\
\hline \multicolumn{4}{|c|}{ Risk of infection (r.c. like rest of population) } \\
\hline Less than others & $\begin{array}{c}-0.108 \\
(0.076)\end{array}$ & $\begin{array}{c}0.141 \\
(0.103)\end{array}$ & $\begin{array}{c}-0.334^{\star \star \star} \\
(0.097)\end{array}$ \\
\hline More than others & $\begin{array}{c}0.011 \\
(0.051)\end{array}$ & $\begin{array}{c}0.157^{\star} \\
(0.073)\end{array}$ & $\begin{array}{c}-0.003 \\
(0.059)\end{array}$ \\
\hline Trust in parliament & $\begin{array}{c}-0.116^{\star \star \star} \\
(0.010)\end{array}$ & $\begin{array}{c}-0.120^{\star \star \star} \\
(0.013)\end{array}$ & $\begin{array}{c}-0.042^{\star \star \star} \\
(0.011)\end{array}$ \\
\hline \multicolumn{4}{|c|}{ Propensity to vote: high (r.c. low): } \\
\hline Ptv Lega: high & $\begin{array}{l}1.207^{\star \star \star} \\
(0.057)\end{array}$ & $\begin{array}{l}1.043^{\star * \star} \\
(0.075)\end{array}$ & $\begin{array}{c}0.199^{\star \star} \\
(0.076)\end{array}$ \\
\hline Ptv M5S: high & $\begin{array}{l}0.202^{\star \star \star} \\
(0.060)\end{array}$ & $\begin{array}{l}0.496^{\star * \star} \\
(0.080)\end{array}$ & $\begin{array}{c}-0.009 \\
(0.071)\end{array}$ \\
\hline Constant & $\begin{array}{c}-1.201^{\star * \star} \\
(0.145)\end{array}$ & $\begin{array}{c}-2.289^{\star * \star} \\
(0.200)\end{array}$ & $\begin{array}{c}-1.623^{* \star *} \\
(0.173)\end{array}$ \\
\hline Log-likelihood & $-13,737.235$ & & \\
\hline Sig. & 0.000 & & \\
\hline
\end{tabular}

r.c., Reference category.

Standard errors in parentheses. $N=12,573$

$+P<0.10,{ }^{\star} P<0.05,{ }^{\star *} P<0.01,{ }^{\star *} P<0.001$.

\section{The interaction between trust in institutions and political orientation}

Finally, what can be said about the interaction between institutional trust and political orientation on the probability of endorsing ATOCs? Model 6 in Table 3 reports the coefficients of the interaction between trust in parliament and propensity to vote for the M5s or Lega. To ease the interpretation of the results, we move to Figure 1 which plots the predicted probabilities of endorsing each of the possible origins of the virus by trust in the national parliament for subjects with a high propensity to vote for M5s and Lega.

First, looking at the panel on the left concerning the probability of endorsing the answer referring to failed scientific experiments, the most popular ATOC in our sample, it is clear that the association between trust in the national parliament and the outcome varies considerably between the respondents with high ptv for Lega and the ones with high ptv for M5s - as shown by the far steeper line for the former. While Lega and M5s supporters have similar (and relatively low) probabilities of believing that the origin of the Coronavirus is in failed scientific experiments when they have high trust in the national parliament, their probabilities diverge considerably at a lower level of trust, with Lega supporters being much more likely to believe in this ATOC compared to M5s supporters. This pattern is confirmed when considering the probabilities of endorsing the official explanation of zoonosis as the origin of the Coronavirus (central panel). Also in this case, trust in the national parliament seems to matter more among Lega supporters, to the point that, at higher levels of trust, they do not differ much from M5s supporters. In contrast, at low levels of trust, the latter have higher chances of believing in the official explanation compared to the former. The pattern is less clear for the option 'war between USA and China' that is the least popular option and shows rather low predicted probabilities across all levels of trust. Overall, the results back up our expectation of the moderating role of political orientation on the association between institutional trust and belief in ATOCs (Hypothesis 5). 
Table 3. Multinomial logit (Model 6) predicting the probable origin of SARS-CoV-2, r.c.: official explanation

\begin{tabular}{|c|c|c|c|}
\hline & \multicolumn{3}{|c|}{ Model 6} \\
\hline & Scientific experiments & War US and China & Don't know \\
\hline Hiding real number of cases & $\begin{array}{l}0.215^{\star \star \star} \\
(0.008)\end{array}$ & $\begin{array}{l}0.287^{\star \star \star} \\
(0.012)\end{array}$ & $\begin{array}{l}0.118^{\star \star \star} \\
(0.009)\end{array}$ \\
\hline \multicolumn{4}{|c|}{ Change in economic situation (r.c. no change) } \\
\hline Worsened & $\begin{array}{l}0.212^{\star \star \star} \\
(0.054)\end{array}$ & $\begin{array}{c}0.170^{\star} \\
(0.076)\end{array}$ & $\begin{array}{c}0.104 \\
(0.064)\end{array}$ \\
\hline Worsened a lot & $\begin{array}{l}0.401^{\star \star *} \\
(0.089)\end{array}$ & $\begin{array}{l}0.495^{\star \star \star} \\
(0.114)\end{array}$ & $\begin{array}{c}0.268^{\star} \\
(0.107)\end{array}$ \\
\hline \multicolumn{4}{|c|}{ Risk of infection (r.c. like rest of population) } \\
\hline Less than others & $\begin{array}{c}-0.102 \\
(0.076)\end{array}$ & $\begin{array}{c}0.133 \\
(0.103)\end{array}$ & $\begin{array}{c}-0.335^{\star \star \star} \\
(0.097)\end{array}$ \\
\hline More than others & $\begin{array}{c}0.008 \\
(0.051)\end{array}$ & $\begin{array}{r}0.164^{\star} \\
(0.073)\end{array}$ & $\begin{array}{c}-0.002 \\
(0.059)\end{array}$ \\
\hline Trust in parliament & $\begin{array}{l}-0.117^{\star \star \star} \\
(0.012)\end{array}$ & $\begin{array}{c}-0.158^{\star \star \star} \\
(0.018)\end{array}$ & $\begin{array}{c}-0.043^{\star *} \\
(0.014)\end{array}$ \\
\hline \multicolumn{4}{|c|}{ Propensity to vote: High (r.c. low) } \\
\hline Five Star Movement & $\begin{array}{c}-0.173 \\
(0.140)\end{array}$ & $\begin{array}{c}0.113 \\
(0.175)\end{array}$ & $\begin{array}{c}0.014 \\
(0.169)\end{array}$ \\
\hline Lega & $\begin{array}{l}1.350^{\star \star \star *} \\
(0.106)\end{array}$ & $\begin{array}{l}0.848^{\star \star \star} \\
(0.136)\end{array}$ & $\begin{array}{c}0.173 \\
(0.144)\end{array}$ \\
\hline \multicolumn{4}{|c|}{ Interaction: propensity to vote $\times$ trust } \\
\hline Five Star Movement $\times$ trust & $\begin{array}{l}0.072^{\star \star} \\
(0.023)\end{array}$ & $\begin{array}{c}0.068^{\star} \\
(0.030)\end{array}$ & $\begin{array}{c}-0.006 \\
(0.028)\end{array}$ \\
\hline Lega $\times$ trust & $\begin{array}{c}-0.041+ \\
(0.021)\end{array}$ & $\begin{array}{c}0.045+ \\
(0.027)\end{array}$ & $\begin{array}{c}0.007 \\
(0.028)\end{array}$ \\
\hline Constant & $\begin{array}{c}-1.177^{\star \star \star} \\
(0.150)\end{array}$ & $\begin{array}{c}-2.140^{\star \star \star} \\
(0.206)\end{array}$ & $\begin{array}{c}-1.620^{\star \star \star} \\
(0.177)\end{array}$ \\
\hline Log-likelihood & $-13,723.332$ & & \\
\hline Sig. & 0.000 & & \\
\hline
\end{tabular}

r.c., Reference category.

Standard errors in parentheses. $N=12,573$

$+P<0.10,{ }^{\star} P<0.05,{ }^{\star \star} P<0.01,{ }^{\star \star \star} P<0.001$.
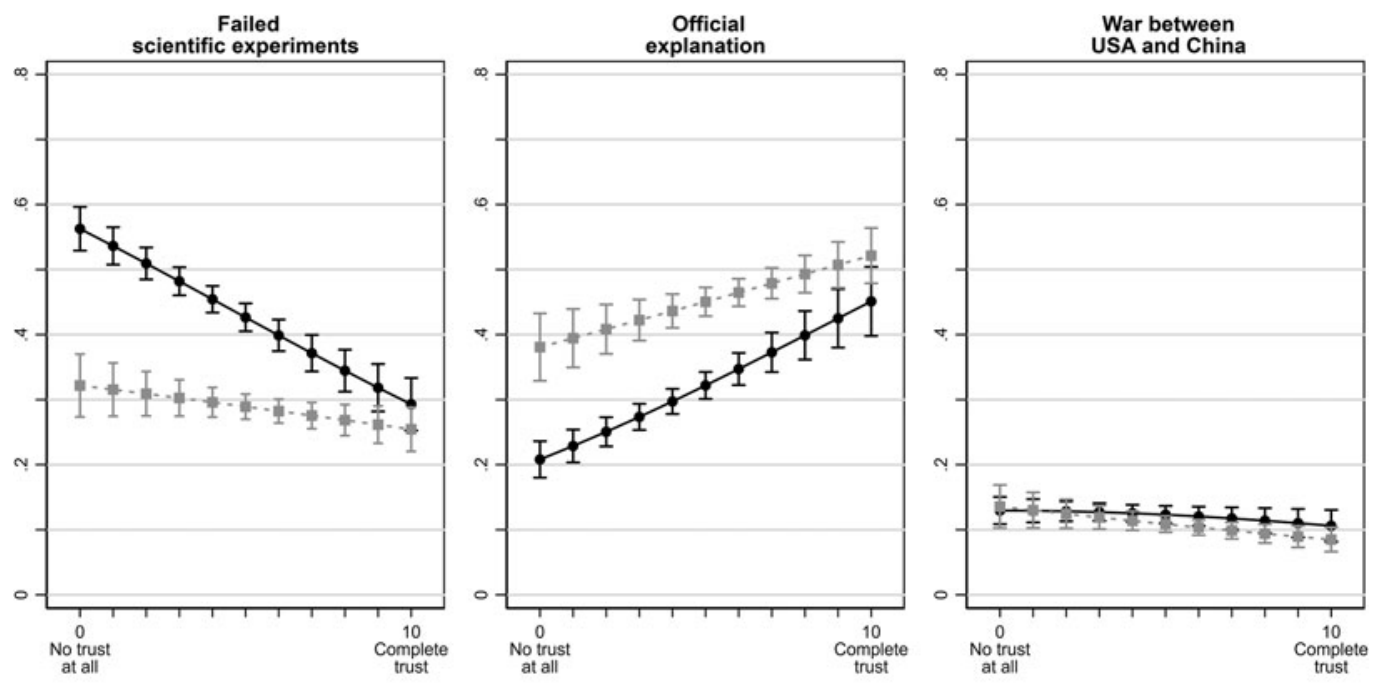

High propensity to vote for:

$\rightarrow$ Lega - M5s

Figure 1. Predicted probabilities for probable origin of the SARS-CoV-2 virus by trust in the national parliament and high propensity to vote (equal or higher than six) for the Five Star Movement and Lega. Predictions are obtained by the coefficients presented in Model 6 in Table 3 and are mean adjusted on all covariates. 


\section{Discussion}

Why is the question on the origin of the SARS-CoV-2 relevant? Because it shows where the threat to global health comes from and the answer could suggest what are the possible actions to contrast it, from its origins. Is the virus stemming from natural processes or is it man-made? And, if it is natural, was it made more serious by the conditions created by the huge impact of human activities on the environment? When science was confronted with the spread of a new virus, now known as SARS-CoV-2, provoking an unknown disease, COVID-19, with very severe consequences, it quickly came to the conclusion that the Coronavirus pandemic was the effect of zoonotic transmission, that is the transmission of a virus from an animal to human beings (Andersen et al., 2020). These zoonoses are not a new phenomenon but the depletion of huge portions of the wild environment seems to have caused an increase in these events, as a consequence of the growing likelihood of contacts between wild animals and human beings (Quammen, 2013). Nonetheless, alternative theories on the origin of the virus (ATOCs), which were scientifically disproven and containing conspirational elements, spread among the public, for example, in the US (Mitchell et al., 2020; Miller, 2020a).

Our study shows that ATOCs received the endorsement of a substantial portion of the public also in Italy. In the period from April to July 2020, the data show that this proportion was close to $50 \%$. Although our sample is not strictly representative of the Italian population, our percentage could even underestimate the actual figure, given that our sample is biased towards a higher level of education, and education is steadily associated with a lower probability of endorsing ATOCs (see online Appendix). Our result proves that beliefs in ATOCs are not residual among the Italian public. Moreover, these beliefs are more frequent in those who are more susceptible to conspiratorial thinking, confirming that ATOCs can be included in the large family of conspiracy theories.

Our analysis shows an association between the support for ATOCs and perceived threats induced by the pandemic, but only as far as the household economic situation is concerned. Indeed, the probability of believing in ATOCs increases when the financial situation of the household worsens due to the pandemic. This is not the case if a person perceives a higher health risk compared to the rest of the population. This finding suggests that the impact of the pandemic could go far beyond the period of the health emergency.

Also, we found institutional trust to be a crucial factor affecting the probability to back ATOCs (odds for the lowest level of trust vs. the highest level of trust $>3$ ). In our view, institutional trust is the most persistent, driving factor that affects beliefs in ATOCs. This contrasts the view that beliefs in conspiracy theories are mainly the result of (politically) motivated reasoning (Miller et al., 2016). As the issue of the origins of the virus was not politicized in Italy, the ground for such an explanation in that context is shaky. Politics plays indeed a role in our model, as manifest preferences for right-wing or populist parties increase the probability of endorsing ATOCs. However, this seems to happen through other mechanisms, rather than motivated reasoning. On the one side, there is room for cue-taking from the leaders of the parties; on the other side, the effect of partisanship can change if the party happens to be in the government or at the opposition. In Italy, this is the case when comparing Lega and Five Star Movement. The supporters of both parties are more likely to back ATOCs, but the effect is stronger for Lega, which was in the opposition at the time of data collection.

Possibly the most significant result of our analysis is that politics matters because it mediates the effect of institutional trust. Partisanship can amplify or dampen this effect. Comparing supporters of Lega and M5s, we see that the effect of Lega supporters is stronger. In short, low trust in institutions and support for Lega produce the ideal combination to endorse ATOCs. Why is it so? A possible reason could be that the sceptical attitudes towards the official accounts concerning the Coronavirus produced by low levels of trust are coherent with the cues one obtains from the (opposition) party she supports. This mechanism is ignited to the extent that the opposition party takes the issue of the pandemic as an opportunity to criticize the action of the government. 
This outcome is of particular concern in contexts of widespread distrust in institutions and high political polarization. The instrumental use of un-scientific arguments to discredit the political opponents can foster a large circulation of these opinions, finding fertile ground in the already widespread low level of trust in institutions. This can happen especially among supporters of those parties that embrace these views as a tool of political competition. The two elements can eventually come to reinforce each other: low trust increases the probability to believe in conspiratorial, alternative, scientifically baseless accounts, and belief in these accounts further promote the idea that the government does not tell citizens the truth.

In the specific context of a pandemic, this spiral can have a significant dysfunctional impact, both in the short term as it weakens the authority of the government in enacting measures meant to contrast the diffusion of the virus, and in the long term, as it can make even a more distinguished victim: trust in science. In fact, in our specific case, the contentious topic of the origin of the virus opposed the account of the official science with alternative unproven accounts. At the end of the day, a public debate in which those two elements are put on the same level can convey the dangerous message that scientific evidence can be challenged by opinions and not through scientific scrutiny.

\section{Limitations}

The last point to address concerns the reach of the results presented in this article.

Firstly, we acknowledge that several of our measures are built considering only one indicator, being the dependent variable the most relevant example. We are aware of the problems such an approach brings to the quality of measurement. Nonetheless, our choice was bound to the availability of indicators in a survey that was originally not devoted to the study of conspiratorial thinking and beliefs in COVID-19-related conspiracies. We thought that our topic was timely in the backdrop of the worldwide pandemic, and worth investigating it even if with sub-optimal measurement. This limitation invites caution in the evaluation of the results.

Secondly, our arguments are built on evidence derived from a cross-sectional sample. Clearly, the indication of causal relations can only be hypothesized, and the logic of our theoretical model could also be altered in the fashion presented in previous literature. We acknowledge this limitation, which is inherent to all analyses based on correlational data. A possible way out of this shortcoming could be a strategy including a panel design, where the information concerning the antecedents of the beliefs to be studied, in our case on ATOCs, is collected in a previous wave of the survey. This point underlines the importance of thorough planning of the research design to obtain data that can bring to more robust conclusions.

\section{Conclusion}

To conclude, although the data on which our conclusions are based refer to a specific context (Italy) in the very particular moment of the first Coronavirus pandemic outbreak, we have good reason to think that our argument can be applied to the more general discussion on the mechanisms underlying the spread and endorsement of conspiracy theories. Firstly, it has regularly been observed that trust in institutions is significantly connected with conspiratorial ideation. Secondly, the consideration of partisanship as a more transient element compared to institutional trust is extremely plausible, at least in the European context. Thus, it seems reasonable to see partisanship as an intervening factor rather than the actual origin of beliefs in conspiracy theories. Of course, these statements hold the status of hypotheses, and only further systematic and comparative research on the topic could show whether our guesses were correct.

Supplementary material. The supplementary material for this article can be found at https://doi.org/10.1017/ipo.2021.19 
Funding. The research 'Response of the Italian Public Opinion to the COVID-19 Emergency - ResPOnsE COVID-19' was made possible thanks to the funding received by the Department of Social and Political Sciences, University of Milan Statale, within the program 'Department of Excellence 2018-2022' (DM 262/ 2017) of the Ministry of Education, Universities and Research (MIUR).

Data. The replication syntax is available at http://thedata.harvard.edu/dvn/dv/ipsr-risp. The replication dataset is currently available on request from the corresponding author.

Acknowledgements. The authors would like to thank the two anonymous reviewers for their insightful comments and the staff at SWG s.r.l, in particular Alessandra Dragotto, Phd, for their support and availability during the fieldwork.

Authorship note. This article is the result of a joint effort of the SPS TREND research team. Cristiano Vezzoni, Giulia M. Dotti Sani, Antonio M. Chiesi and Riccardo Ladini contributed to the design and implementation of the research, to the analysis of the results and to the writing of the manuscript. Ferruccio Biolcati, Simona Guglielmi, Nicola Maggini, Marco Maraffi, Francesco Molteni, Andrea Pedrazzani and Paolo Segatti contributed to the design and implementation of the research, provided critical feedback, and helped shape the manuscript.

Conflict of interest. None.

\section{References}

Andersen KG, Rambaut A, Lipkin WI, Holmes EC and Garry RF (2020) The proximal origin of SARS-CoV-2. Nature Medicine 26, 450-452.

Ansa (2020) Coronavirus: Il caso del video del Tgr Leonardo 2015 sul supervirus creato in Cina. Ansa, 25 March. Available at http://www.ansa.it/sito/notizie/politica/2020/03/25/coronavirus-il-caso-del-video-del-tgr-leonardo-2015-sul-superviruscreato-in-cina_7adf8316-6ca5-42cd-96de-c18f7fb53595.html

Blank JM and Shaw D (2015) Does partisanship shape attitudes toward science and public policy? The case for ideology and religion. The ANNALS of the American Academy of Political and Social Science 658, 18-35.

Brady HE and Johnston R (2006) The rolling cross-section and causal attribution. In Brady HE and Johnston R (eds), Capturing Campaign Effects. Ann Arbor: University of Michigan Press, pp. 164-195.

Brady HE and Johnston R (2015) Repeated cross-sections in survey data. In Scott RA, Kosslyn SM and Buchmann M (eds). Emerging Trends in the Social and Behavioral Sciences. Atlanta, Georgia, United States: American Cancer Society, pp. 1-18.

Brotherton R, French CC and Pickering AD (2013) Measuring belief in conspiracy theories: the Generic Conspiracist Beliefs scale. Frontiers in Psychology 4: 279. https://doi.org/10.3389/fpsyg.2013.00279

Chiaramonte A and Emanuele V (2017) Party system volatility, regeneration and de-institutionalization in Western Europe (1945-2015). Party Politics 23, 376-388.

Douglas KM, Sutton RM and Cichocka A (2017) The psychology of conspiracy theories. Current Directions in Psychological Science 26, 538-542.

Einstein KL and Glick DM (2015) Do I think BLS data are BS? The consequences of conspiracy theories. Political Behavior 37(3), 679-701.

Emanuele V and Chiaramonte A (2019) Explaining the impact of new parties in the Western European party systems. Journal of Elections, Public Opinion and Parties 29, 490-510.

Emanuele V and Chiaramonte A (2020) Going out of the ordinary. The de-institutionalization of the Italian party system in comparative perspective. Contemporary Italian Politics 12, 4-22.

Guardian (2020a) 'Not racist at all': Donald Trump defends calling coronavirus the 'Chinese virus' - video. The Guardian, 18 March. Available at https://www.theguardian.com/world/video/2020/mar/18/not-racist-at-all-donald-trump-defends-calling-coronavirus-the-chinese-virus-video

Guardian (2020b) Trump claims to have evidence coronavirus started in Chinese lab but offers no details. The Guardian, 1 May. Available at https://www.theguardian.com/us-news/2020/apr/30/donald-trump-coronavirus-chinese-lab-claim

Johnston R (2008) Modeling campaign dynamics on the web in the 2008 National Annenberg Election Study. Journal of Elections, Public Opinion and Parties 18, 401-412.

Johnston R and Brady HE (2002) The rolling cross-section design. Electoral Studies 21, 283-295.

Kunda Z (1990) The case for motivated reasoning. Psychological Bulletin 108, 480-498.

Lodge $\mathbf{M}$ and Taber C (2000) Three steps toward a theory of motivated political reasoning. In Lupia A, McCubbins MD and Popkin SL (eds). Elements of Reason: Cognition, Choice, and the Bounds of Rationality. Cambridge: Cambridge University Press, pp. 183-213.

Long JS and Freese J (2014) Regression Models for Categorical Dependent Variables Using Stata, 3rd Edn. edn, Lakeway Drive: Stata Press.

Mancosu M, Vassallo S and Vezzoni C (2017) Believing in conspiracy theories: evidence from an exploratory analysis of Italian survey data. South European Society and Politics 22, 327-344. doi: 10.1080/13608746.2017.1359894 
Miller JM (2020a) Do COVID-19 conspiracy theory beliefs form a monological belief system? Canadian Journal of Political Science/Revue Canadienne de Science Politique 53, 319-326.

Miller JM (2020b) Psychological, political, and situational factors combine to boost COVID-19 conspiracy theory beliefs. Canadian Journal of Political Science 53, 327-334.

Miller JM, Saunders KL and Farhart CE (2016) Conspiracy endorsement as motivated reasoning: the moderating roles of political knowledge and trust. American Journal of Political Science 60, 824-844.

Mitchell A and Oliphant BJ (2020) Americans immersed in coronavirus news; most think media are doing fairly well covering it. Pew Research Center's Journalism Project, 18 March. Available at https://www.journalism.org/2020/03/18/americans-immersed-in-covid-19-news-most-think-media-are-doing-fairly-well-covering-it/

Mitchell A, Jurkowitz M, Oliphant JB and Shearer E (2020) Three months in, many Americans see exaggeration, conspiracy theories and partisanship in COVID-19 news. Pew Research Center's Journalism Project, 29 June. Available at https:/ www.journalism.org/2020/06/29/three-months-in-many-americans-see-exaggeration-conspiracy-theories-and-partisanship-in-covid-19-news/

National Geographic (2020) Fauci: no scientific evidence the coronavirus was made in a Chinese lab. National Geographic, 4 May. Available at https:/www.nationalgeographic.com/science/2020/05/anthony-fauci-no-scientific-evidence-the-coronavirus-was-made-in-a-chinese-lab-cvd/

Nisbet EC, Cooper KE and Garrett RK (2015) The partisan brain: how dissonant science messages lead conservatives and liberals to (dis)trust science. Annals of the American Academy of Political and Social Science 658, 36-66.

Oliver JE and Wood TJ (2014) Conspiracy theories and the paranoid style(s) of mass opinion. American Journal of Political Science 58, 952-966.

Qiu Y, Zhao Y-B, Wang Q, Li J-Y, Zhou Z-J, Liao C-H and Ge X-Y (2020) Predicting the angiotensin converting enzyme 2 (ACE2) utilizing capability as the receptor of SARS-CoV-2. Microbes and Infection 22, 221-225.

Quammen D (2013) Spillover: Animal Infections and the Next Human Pandemic. New York: Norton \& Company.

Repubblica (2020) Zaia: 'Se virus perde forza, è artificiale'. E Pregliasco: 'Non si può escludere in maniera totale, ma dati indicano che è naturale’. La Repubblica, 9 May. Available at https://www.repubblica.it/cronaca/2020/05/09/news/zaia_se_ virus_perde_forza_e_artificiale_e_pregliasco_non_si_puo_escludere_in_maniera_totale_ma_dati_indicano_che_e_n-256181038/

Reuters (2020) Italian regional chief sorry for saying Chinese eat 'live mice'. Reuters, 29 February. Available at https://www. reuters.com/article/china-health-italy-idUSL8N2AT0G3

Shin ME and Agnew JA (2008) Berlusconi's Italy: Mapping Contemporary Italian Politics. Philadelphia: Temple University Press.

Šrol J, Mikušková EB and Čavojová V (2021) When we are worried, what are we thinking? Anxiety, lack of control, and conspiracy beliefs amidst the COVID-19 pandemic. Applied Cognitive Psychology, First published: 01 February 2021. doi: https://doi.org/10.1002/acp.3798.

Sunstein CR and Vermeule A (2009) Conspiracy theories: causes and cures. Journal of Political Philosophy 17, $202-227$.

Uscinski JE and Parent JM (2014) American Conspiracy Theories. Oxford: Oxford University Press.

Uscinski JE, Klofstad C and Atkinson MD (2016) What drives conspiratorial beliefs? The role of informational cues and predispositions. Political Research Quarterly; Salt Lake City 69, 57-71.

van Prooijen J-W and Acker M (2015) The influence of control on belief in conspiracy theories: conceptual and applied extensions. Applied Cognitive Psychology 29, 753-761.

Vezzoni C, Ladini R, Molteni F, Dotti Sani GM, Biolcati F, Chiesi AM, Maraffi M, Guglielmi S, Pedrazzani A and Segatti P (2020) Investigating the social, economic and political consequences of Covid-19: a rolling cross-section approach. Survey Research Methods 14, 187-194.

World Health Organization (2021) WHO-convened global study of origins of SARS-CoV-2: China Part. WHO Headquarters. Available at https://www.who.int/publications/i/item/who-convened-global-study-of-origins-of-sars-cov-2china-part

Zaller JR (1992) The Nature and Origins of Mass Opinion. Cambridge: Cambridge University Press.

Zhou P, Yang X-L, Wang X-G, Hu B, Zhang L, Zhang W, Si H-R, Zhu Y, Li B, Huang C-L, Chen H-D, Chen J, Luo Y, Guo H, Jiang R-D, Liu M-Q, Chen Y, Shen X-R, Wang X, Zheng X-S, Zhao K, Chen Q-J, Deng F, Liu L-L, Yan B, Zhan F-X, Wang Y-Y, Xiao G-F and Shi Z-L (2020) A pneumonia outbreak associated with a new coronavirus of probable bat origin. Nature 579, 270-273.

Cite this article: Vezzoni C et al (2022). Where does the Coronavirus come from? On the mechanisms underlying the endorsement of conspiracy theories on the origin of SARS-CoV-2. Italian Political Science Review/Rivista Italiana di Scienza Politica 52, 51-65. https://doi.org/10.1017/ipo.2021.19 